\title{
OPTIMASI KOMPOSISI KIRIMAN TEBU UNTUK MENCAPAI HASIL GULA OPTIMAL DI PT. INDOLAMPUNG PERKASA KABUPATEN TULANG BAWANG, LAMPUNG
}

\section{Optimization of Shipments Composition of Sugar Cane to Achieve Optimal Results at Regency Tulang Bawang at PT. Indolampung Perkasa, Lampung}

\author{
Tri Sunu Budi Artha ${ }^{1}$, Dwidjono Hadi Darwanto ${ }^{2}$ dan Lestari Rahayu Waluyati ${ }^{2}$ \\ ${ }^{1)}$ Pascasarjana Ekonomi Pertanian Fakultas Pertanian Universitas Gadjah Mada \\ ${ }^{2)}$ Fakultas Pertanian Universitas Gadjah Mada
}

\begin{abstract}
Sugarcane in PT. ILP harvested by harvesting division through logging, unloading and transport. Logging is done in the form of sugar cane burn. The existence of a span of fuel to burn the sugar cane milling can undergo metabolism that cause decomposition of biodegradable polysaccharides into monosaccharides or disaccharides, resulting in reduced cane sugar. Therefore, logging and proper and efficient transport can reduce the rate of decline in the value of pol and purity. Logging and transport in PT. ILP is done in three systems, namely Bundle Cane, Loose Cane, and Chopped Cane.

This study aimed to determine: (i) differences in the ability of the system to send Cane Bundle, Loose Cane, and Chopped Cane, and (ii) the composition of the optimal delivery system Cane Bundle, Loose Cane, and Chopped Cane. This study used a descriptive analytical method. The type of data collected and analyzed secondary data of sugarcane to the factory shipment in 2012 and in 2013 from Harvesting Division PT. ILP be burnt to crush report time (hour) per weeks. Methods of data analysis using quantitative analysis method of linear programming models.

The results showed that there are differences in the average shipment of sugar cane to the factory PT. ILP systems Bundle Cane, Cane Loose, and Chopped Cane Cane Bundle cutting system where the highest followed Loose Cane cutting system and the smallest is the Chopped Cane cutting system. In addition, the results of the study also concluded that the average composition of the shipment of cutting system Bundle Cane, Cane Loose, and Chopped Cane currently not optimal in meeting the quota factory. This is evident from the composition of the shipment allocation of sugarcane to the factory PT. ILP on each cutting system (Bundle Cane, Cane Loose, and Chopped Cane) to change the composition of the previous allocation so that a change in the composition is still obtainable sugar production higher than before (still can be improved). A change in the number of workers cutting and variable costs per ton of cane will change the composition of the optimal number of items cane to the mill.
\end{abstract}

Key words: bundle cane, loose cane, chopped cane, shipment, optimization

\section{PENDAHULUAN}

Tebu di PT. ILP dipanen oleh divisi harvesting melalui kegiatan tebang, muat dan angkut. Kegiatan tebang dilakukan dalam bentuk tebu bakar dan diangkut dalam 3 sistem, yaitu Bundle Cane (BC), Loose Cane (LC), dan Chopped Cane (CC). Tebu dikirim ke pabrik untuk diproses lebih lanjut menjadi gula. Sistem tebang Bundle Cane adalah sistem tebang dan muat yang dilakukan secara manual dalam bentuk tebu ikat. Setiap beberapa batang tebu diikat, kemudian sejumlah ikatan tersebut dimuat kedalam truk terbuka/tanpa bak. Rata-rata dalam satu rit truk dapat memuat 10 sampai dengan 20 ton tebu. Sistem ini dilakukan secara borongan termasuk dalam penyediaan armada truk.
Sistem tebang LC adalah sistem tebang dan muat secara semi mekanik. Sistem tebangnya dilakukan secara manual, tebu ditumpuk secara teratur dalam setiap 8 baris satu lajur tumpukan. Dalam satu lajur tumpukan tersebut, tebu ditata secara rapi menjadi beberapa titik tumpukan. Kemudian titik tumpukan ini dimuat secara mekanik menggunakan Grab loader ke STT (unit pentrasfer tebu yang bernama Side Tiping Trailer) trailer dan dari STT trailer ke tronton. Rata-rata dalam satu set tronton dapat memuat 30 sampai dengan 50 ton tebu. Sistem ini dilakukan secara borongan pada tebangnya saja. Muat dan angkut dilakukan menggunakan aset perusahaan.

Sistem CC adalah sistem tebang yang murni dilakukan secara mekanik. Tebang dilakukan menggunakan cane harvester, muat 
menggunakan STT trailer dan angkut menggunakan tronton. Secara keseluruhan sistem ini menggunakan aset perusahaan. Tebang dan angkut dari ketiga sistem tersebut akan mengalami gangguan pada saat hujan, karena hujan bisa menghambat proses bakar, dan air hujan dapat membuat jalan becek dan licin untuk dilalui kendaraan angkut. Akan tetapi ada faktor penghambat yang spesifik terhadap ketiga sistem angkut. Kuota harian di PT. ILP adalah 8.500 ton/hari.

Tiga sistem tersebut dikembangkan karena masing-masing sistem mempunyai karakter yang berbeda dan dapat saling menutupi kekurangan satu sama lain dalam usaha memenuhi kuota harian pabrik. BC mempunyai keterbatasan pada ketersediaan tenaga tebang. Tenaga tebang $\mathrm{BC}$ mempunyai karakteristik khusus dan kekuatan lebih. Karena mereka selain tebang, harus muat tebu diatas truk. Keterampilan ini tidak mudah dimiliki sembarang tenaga. LC dan CC mempunyai keterbatasan pada jumlah unit angkutan yang dimiliki perusahaan. Untuk BC dan LC secara bersama sama memiliki keterbatasan pada dapat tidaknya tebu dibakar, sedangkan CC tidak. Karena CC dilakukan terhadap tebu hijau. Ketiga sistem ini juga secara bersama-sama memiliki keterbatasan modal, baik dari pelaksana tebang (untuk BC), maupun modal unit transport bagi perusahaan (untuk LC, dan $\mathrm{CC})$.

\section{DASAR TEORI}

\section{Teori Produksi}

Produksi dapat dinyatakan sebagai seperangkat prosedur dan kegiatan yang terjadi dalam penciptaan produk atau jasa. Sedangkan pengolahan adalah perubahan bentuk dari sejumlah bahan dasar agar lebih mudah dipasarkan. Manajemen produksi yaitu rangkaian keputusan yang rumit guna mendukung proses produksi. Pada agribisnis, prinsip-prinsip manajemen produksi terbukti telah bermanfaat dalam memperbaiki metode pengumpulan, penyortiran, dan pengelompokkan mutu, pemrosesan dan pabrikasi, dan pengepakan, serta pengiriman produk pertanian (Downey, dan Erickson, 1987). Menurut Debertin (1986), fungsi produksi terdapat hubungan teknis antara faktor-faktor produksi yang disebut input dan hasil produksi yang disebut output. Disebut faktor produksi karena adanya sifat mutlak agar produksi dapat dijalankan dan menghasilkan produksi, yakni:

$$
\begin{array}{ll}
q=f\left(X_{1}, X_{2}, X_{3}, \ldots . X n\right) & \\
\text { dimana : } & =\text { produk } \\
q & =\text { input yang digunakan }
\end{array}
$$

Penambahan input dalam proses produksi tidak selalu menyebabkan tambahan output semakin besar, seperti yang dikemukakan oleh Darwanto (1982) bahwa sifat dari fungsi produksi pertanian pada umumnya tunduk pada suatu hukum yang dikenal dengan The Law of Deminishing Return. Hukum tersebut mengatakan bahwa jika suatu input ditambahkan penggunaannya di dalam suatu proses produksi dengan kuantitas penggunaan input yang lain tetap, maka tambahan output yang diperoleh dari setiap tambahan input yang ditambahkan tersebut pada mulanya akan selalu naik, tetapi penambahan input selanjutnya justru akan memberikan hasil yang semakin menurun. Efisiensi teknis adalah perbandingan antara besarnya produksi yang benar-benar dicapai (produksi aktual) dengan produksi potensial. Suatu produksi dikatakan efisien bila nilai efisiensi produksinya mendekati 1 .

Fungsi produksi yang mendasari model LP biasa disebut fixed-proportion production function. Model ini antar input tidak dapat mensubstitusi satu sama lain dan bersifat constant return to scale, sedangkan pada fungsi produksi linear, input dapat saling mensubstitusi (Debertin, 1986).

\section{Linear Programming}

Linear Programming (LP) merupakan alat untuk analisis masalah yaitu suatu fungsi linear dari sejumlah variabel perlu dimaksimumkan atau diminimumkan, sedang sejumlah variabel tersebut dibatasi oleh sejumlah kendala. LP juga dapat digunakan sebagai perencanaan usaha pertanian. Perencanaan perlu, mengingat banyak tersedia alternatif, dan alternatif terbaik dapat ditentukan dengan kendala yang ada (Beneke dan Winterboer, 1973). 
Menurut Taha dalam Hartono (2000), LP merupakan teknik optimasi yang tujuan dan kendalanya dinyatakan sebagai fungsi linier dari variabel keputusan. Kelemahan dari model LP ini adalah sifatnya yang deterministik dalam artian bahwa semua parameter yang menyusun model ini diketahui secara pasti. Padahal dalam kenyataannya jarang dijumpai parameter yang sifatnya pasti atau tanpa kesalahan. Untuk mengatasi masalah ini maka dilakukan analisis sensitivitas.

LP merupakan salah satu alternatif alat analisis pengambilan keputusan yang relatif cepat. Penyelesaian optimasi dengan menggunakan LP dapat dipisahkan menjadi dua macam yaitu metode grafis dan metode simplex (Beneke dan Winterboer, 1973). Tujuan mengoptimalkan alokasi sumberdaya disamping untuk memaksimalkan keuntungan atau minimasi biaya, juga tercapainya penggunaan sumberdaya secara efisien. Dengan demikian terdapat hubungan yang erat antara fungsi produksi dengan linear progamming.

Menurut Subagyo et al., 2013), metode LP merupakan metode pengalokasian sumber daya yang terbatas untuk mencapai tujuan-tujuan tertentu dalam bentuk matematik. Fungsi dalam model LP terdiri dari fungsi tujuan (objective function) dan fungsi kendala (costraint function). Fungsi tujuan adalah fungsi yang menjadi sasaran di dalam permasalahan LP yang berkaitan dengan pengaturan secara optimal sumber daya, untuk memperoleh keuntungan maksimal atau biaya minimal. Menurut Asri dan Widayat (1986) dalam menyusun suatu model LP ditempuh beberapa langkah sebagai berikut: (i) menentukan aktivitas, (ii) menentukan sumberdaya, (iii) menghitung input dan output tiap aktivitas (disebut sebagai koefisien aktivitas), (iv) menentukan kapasitas kendala, dan, (v) menyusun model LP. Untuk mempermudah dalam pembahasan model LP ini, digunakan simbol-simbol berikut:

$\mathrm{m}$ = macam kendala dari sumber daya atau fasilitas yang tersedia

$\mathrm{n}=$ macam aktifitas yang menggunakan sumber daya atau fasilitas yang tersedia

$\mathrm{i}=$ nomor setiap macam sumber daya atau fasilitas yang tersedia $(\mathrm{i}=1,2,3, \ldots, \mathrm{m})$
$\mathbf{J}=$ nomor setiap aktifitas yang menggunakan sumber daya atau fasilitas

$X_{j}=$ tingkat aktifitas ke-j $(j=1,2,3, \ldots, n)$

$a_{i j}=$ banyaknya sumberdaya ke-1 yang diperlukan untuk menghasilkan setiap unit output kegiatan $(i=1,2,3, \ldots, m$; dan $\mathrm{j}=1,2,3, \ldots, n$ )

$b_{i}=$ banyaknya sumber daya ke-I yang tersedia untuk dialokasikan ke setiap unit kegiatan $(\mathrm{i}=1,2,3, \ldots, \mathrm{n})$

$\mathrm{Z}=$ nilai dioptimalkan (maksimum atau minimum)

$\mathrm{C}_{\mathrm{j}}=$ kenaikan nilai $\mathrm{Z}$ apabila ada pertambahan tingkat kegiatan $\left(\mathrm{X}_{\mathrm{j}}\right)$ dengan satu satuan (unit), atau merupakan sumbangan setiap satuan keluaran kegiatan ke-j terhadap nilai $Z$

Keseluruhan simbol-simbol diatas selanjutnya disusun suatu model matematis yang digunakan untuk mengemukakan suatu permasalahan LP berikut:

Fungsi tujuan:

Maksimumkan

$$
Z=C_{1} X_{1}+C_{2} X_{2}+C_{3} X_{3}+\ldots \ldots+C_{n} X_{n}
$$

Kendala:

1. $a_{11} X_{1}+a_{12} X_{2}+a_{13} X_{3}+\ldots .+a_{1 n} X_{n} \leq b_{1}$

2. $a_{21} X_{1}+a_{22} X_{2}+a_{23} X_{3}+\ldots .+a_{2 n} X_{n} \leq b_{2}$

m. $a_{m 1} X_{1}+a_{m 2} X_{2}+a_{m 3} X_{3}+\ldots .+a_{m n} X_{n} \leq b_{m}$ dan $X_{1}, X_{2}, \ldots ., X_{n} \geq 0$

Bentuk atau model LP di atas merupakan bentuk standar bagi masalah-masalah LP yang akan dipakai selanjutnya. Dengan kata lain bila setiap masalah dapat diformulasikan secara matematis mengikuti model di atas, maka masalah tersebut dapat dipecahkan dengan teknik LP. Menurut Marwan Asri dan Wahyu Hidayat (1984); Nasendi dan Anwar (1984), dalam pemecahan masalah dengan berbagai kondisi dan kendala (constraint) yang dihadapi, diperlukan asumsi dasar dalam programasi linier yang harus dipenuhi, yaitu asumsi dasar tersebut yang harus dipenuhi adalah: linearity of objective, proportionality (proportion of activity level to resources), additivity, deterministic (certaianty) single value expectation, accountability for 
resources, divisibility, dan non negativity of the decision variables.

Setiap persoalan LP selalu memiliki dua macam analisis yang menjadi satu, yaitu analisis primal dan analisis dual yang biasanya disebut analisis primal-dual. Secara umum perubahan bentuk dari persamaan primal menjadi persamaan dual dapat digunakan rumus matematis (Nasendi dan Anwar, 1985) sebagai berikut:

Bentuk primal

Memaksimumkan : $Z=\sum_{j=1}^{n} \mathrm{CjXj}$

Kendala:

$\sum_{j=1}^{n} a_{i j} x_{j} \leq b_{i} ; i=1,2,3, \ldots, m$

$X_{j} \geq 0 ; j=1,2,3, \ldots n$

Bentuk dual

Minimumkan $G=\sum_{i=1}^{m} b i Y i$

Kendala: $\quad \sum_{i=1}^{m}$ aijYi $\leq \mathrm{Cj} ; \mathrm{j}=1,2,3, \ldots, \mathrm{n}$

dimana

$$
Y i \geq 0 ; j=1,2,3, \ldots ., m
$$

$Z^{*}=\sum_{j=1}^{n} \mathrm{CjXj}^{*}$ sama dengan $\mathrm{G}^{*}=\sum_{\mathrm{i}=1}^{\mathrm{m}} \mathrm{biYi}^{*}$

tanda * menunjukkan hasil optimal

Apabila bentuk persamaan-persamaan matematis di atas dirubah dalam bentuk matrik, maka akan diperoleh rumusan seperti terlihat dalam persamaan berikut:

Bentuk primal matrik

Maksimumkan $\mathrm{Z}=\mathrm{C}^{\prime} \mathrm{X}$

kendala

$\mathrm{AX} \leq \mathrm{b}$

$$
\mathrm{X} \geq 0
$$

Bentuk dual matrik

Maksimumkan $\mathrm{G}=\mathrm{b}^{\prime} \mathrm{Y}$

kendala $\quad A^{\prime} Y \geq C$

dimana: $Z^{*}=C^{\prime} X^{*}$ sama saja dengan $G^{*}=b^{\prime} Y^{*}$

\section{Analisis Sensitivitas dalam LP}

Setelah tercapai kondisi optimal kemudian dilakukan analisis sentivitas atau analisis post optimal, atau analisis terhadap persoalan programasi linier setelah tercapainya kondisi optimal dengan menggunakan kaidah-kaidah LP, sehingga akan diketahui sistem tebang mana yang harus dijalankan apabila pilihan dari ketiga sistem tebang yakni $\mathrm{BC}, \mathrm{LC}$ dan $\mathrm{CC}$ menghadapai kendala atau pembatas pada berbagai tingkat sumberdaya yang dimiliki oleh ketiga sistem tersebut.

Analisis sensitivitas dilakukan untuk mengatasi kelemahan model LP yang sifatnya deterministik (Taha, 1996). Analisis ini dilakukan untuk mengetahui sensitivitas atau kepekaan penyelesaian optimal terhadap perubahan parameter fungsi tujuan dan parameter fungsi kendala. Penyelesaian yang tidak terlalu sensitif atau peka terhadap perubahan parameter merupakan penyelesaian yang baik. Analisis sensitivitas ini bertujuan untuk mengetahui apa yang akan terjadi apabila terjadi perubahan pada salah satu, beberapa atau semua persyaratan dalam model LP yang telah disusun. Kemungkinan perubahan dapat terjadi: (i) koefisien fungsi tujuan, (ii) koefisien teknologi, (iii) ketersediaan sumberdaya (kendala), dan (iv) penambahan variabel dan kendala baru.

\section{METODE PENELITIAN}

\section{Jenis Data}

Data yang dikumpulkan adalah data deret waktu (time series), yaitu data Comparative Factory Per Week PT. ILP, alokasi unit Harvesting dan harga dasar tebang tebu selama periode tahun 2012 dan 2013.

\section{Pembatasan Masalah}

Agar analisis dan uraian dalam penelitian ini nantinya lebih terarah dan terfokus, perlu dilakukan batasan-batasan masalah yang jelas. Hal ini dikarenakan adanya keterbatasanketerbatasan yang ada, antara lain yaitu; keterbatasan waktu, kemampuan data, serta keterbatasan lain yang dihadapi dalam penelitian ini. Adapun batasan-batasan masalah yang dilakukan dalam penelitian ini adalah sebagai berikut:

a. Dalam kajian ini nantinya, hanya difokuskan pada PT. ILP dalam hal kemampuan kirim tebu dari sistem tebang $\mathrm{BC}, \mathrm{LC}$ dan CC. 
b. Potensi produksi gula masih dapat ditingkatkan dengan mengoptimalkan kiriman tebu melalui sistem tebang $\mathrm{BC}$, LC dan CC.

c. Dari data deret waktu (time series) dari tahun 2012 sampai dengan tahun 2013.

\section{Asumsi-asumsi}

a. Pihak manajemen PT. ILP dianggap mampu bertindak secara rasional sehingga mampu mempertimbangkan dan memilih alternatif sistem tebang $\mathrm{BC}, \mathrm{LC}$ dan $\mathrm{CC}$ yang paling menguntungkan sesuai dengan kondisi yang ada, dan pihak manajemen PT. ILP berusaha meminimalkan total biaya untuk mencapai keuntungan yang maksimum (optimal).

b. Dalam aktivitas pengiriman tebu dari sistem tebang $\mathrm{BC}, \mathrm{LC}$ dan $\mathrm{CC}$ dapat memenuhi kuota pabrik 8.500 ton per hari dan diasumsikan terjadi siklus yang menghasilkan penerimaan setiap dalam jangka waktu yang telah ditentukan.

c. Variabel-variabel lain yang tidak masuk dalam model-model analisis dianggap tetap.

\section{Metode Analisis}

\section{a. Kuota Harian Pabrik}

Untuk menguji hipotesis pertama, yaitu: "diduga minimal ada satu perbedaan dari perbandingan rerata tebu kiriman dari sistem $\mathrm{BC}$ dengan $\mathrm{LC}, \mathrm{BC}$ dengan $\mathrm{CC}$, dan $\mathrm{LC}$ dengan CC" digunakan analisis Analysis of Variance (ANOVA). Analisis ANOVA digunakan untuk menguji signifikansi perbedaan rata-rata kiriman tebu yaitu sistem: BC, LC dan CC. Analisis varians ini menggunakan variabilitas antar kelompok sebagai pengukur perbedaaan itu dengan perhitungan-perhitungan kuadrat.

\section{b. Komposisi Rerata Kiriman Tebu}

Untuk mengetahui komposisi optimal dari ketiga sistem tersebut, dilakukan dengan LP. Untuk menentukan komposisi rerata kiriman dari sistem tebang $\mathrm{BC}, \mathrm{LC}$ dan $\mathrm{CC}$ yang optimal dalam rangka memenuhi kuota pabrik di gunakan model analisis LP. Sebelum dilakukan analisis terlebih dahulu disusun persamaan fungsi tujuan (objective function) dan fungsi kendala (Constraints function).

\section{1) Fungsi Tujuan (Objective Function)}

Fungsi tujuan dalam penelitian ini adalah komposisi kiriman tebu untuk mencapai hasil gula maksimal. Sasaran dapat dicapai dengan menggunakan alat bantu LP dengan cara merumuskan fungsi tujuan (objective function) sebagai berikut:

Fungsi Tujuan Data Kiriman Tebu Tahun 2012

Max $\mathrm{Z}_{2012}=\mathrm{nbBC}_{2012}+$ obLC $_{2012}+\mathrm{pbCC}_{2012}$

Fungsi Tujuan Data Kiriman Tebu Tahun 2013

Max $Z_{2013}=\mathrm{nlBC}_{2013}+$ olLC $_{2013}+\mathrm{mcCC}_{2013}$

dimana:

$\mathrm{BC}=$ jumlah hari giling $\mathrm{BC}$

LC $=$ jumlah hari giling LC

$\mathrm{CC}=$ jumlah hari giling $\mathrm{CC}$

$\mathrm{nb}=$ kiriman tebu BC (ton/hari) Tahun 2012

$\mathrm{nl}=$ kiriman tebu BC (ton/hari) Tahun 2013

ob = kiriman tebu LC (ton/hari) Tahun 2012

ol = kiriman tebu LC (ton/hari) Tahun 2013

$\mathrm{pb}=$ kiriman tebu/hari CC (ton/hari) Tahun 2012

$\mathrm{mc}=$ kiriman tebu/hari CC (ton/hari) Tahun 2013

Simbol koefisien (nb, nl, dan ob) menggambarkan kemampuan kiriman tebu dari sistem tebang $\mathrm{BC}$, LC, dan $\mathrm{CC}$ tahun 2012 dan simbol koefisien (ol, pb, dan mc) menggambarkan kemampuan kiriman tebu dari sistem tebang $\mathrm{BC}, \mathrm{LC}$, dan $\mathrm{CC}$ tahun 2013 dan merupakan fungsi sasaran optimalisasi kiriman tebu sistem tebang $\mathrm{BC}$, LC, dan CC yang akan dioptimalkan serta simbol BC, LC, dan CC merupakan jumlah hari giling dengan model sistem tebang yang dijalankan selama ini di PT. ILP.

\section{2) Fungsi Kendala (Constraints Function)}

Manajemen PT. ILP selalu dihadapkan pada kendala dalam mengambil suatu keputusan. Hal itu juga berlaku dalam proses pengambilan keputusan menata kemampuan kirim tebu dari ketiga sistem tebang tebu yang digunakan saat ini yaitu sistem tebang $\mathrm{BC}$, LC, dan CC. Misalnya saja, kemampuan kirim maksimal oleh masing-masing sistem tebang (BC, LC, dan CC) jelas merupakan suatu kendala. Disamping itu, terdapat juga kendala 
lain karena berbagai alasan tertentu, seperti: kemampuan kirim maksimal, ketersediaan tenaga tebang $\mathrm{BC}$, ketersediaan tenaga tebang $\mathrm{LC}$, jumlah unit $\mathrm{CC}$, ketersediaan armada angkut $\mathrm{BC}$, ketersediaan armada angkut LC, ketersediaan armada angkut $\mathrm{CC}$, persentase kiriman saat hujan $\mathrm{BC}$, persentase kiriman saat hujan LC, persentase kiriman saat hujan $\mathrm{CC}$, biaya variabel per ton tebu $\mathrm{BC}$, biaya variabel per ton tebu $\mathrm{LC}$, tambahan biaya variabel per ton $\mathrm{BC}$ saat hujan, tambahan biaya variabel per ton LC saat hujan, luas tebangan $\mathrm{BC}$, luas tebangan $\mathrm{LC}$, dan luas tebangan CC.

Koefisien fungsi sasaran terdiri atas variabelvariabel yang bersifat sebagai biaya dan pendapatan, sehingga pada tahap optimal nantinya akan diperoleh nilai tambah (value added) yang optimal. Dalam analisis ini, akan dicari nilai-nilai dari masing-masing koefisien fungsi kendala yang membuat fungsi tujuan (objective function) mempunyai nilai yang maksimal (optimal) tetapi tetap memenuhi syarat-syarat LP.

\section{HASIL PENELITIAN}

\section{Kondisi PT. ILP Saat Ini \\ a. Luas Tebangan}

Total luas tebangan dari ketiga sistem tebang yakni BC, LC, dan CC selama tahün 2012 adalah seluas 18.152,12 Ha dan pada tahun 2013 meningkat $1,50 \%(277,28 \mathrm{Ha})$ atau menjadi $18.429,40 \mathrm{Ha}$. Jika dirinci berdasarkan sistem tebang pada tahun 2012, BC seluas $12.717,67$ $\mathrm{Ha}$; LC seluas 5.082,59 Ha; dan CC seluas 351,86 Ha. Pada tahun 2013, BC meningkat menjadi 14.093,87 Ha atau naik 9,76\%; LC turun $37,52 \%$ atau menjadi $3.695,93 \mathrm{Ha}$; dan $\mathrm{CC}$ meningkat menjadi $639,60 \mathrm{Ha}$ atau naik $44,99 \%$ dari tahun sebelumnya (2012).

Luas lahan tebu (Ha) yang ditebang per minggu dari sistem tebang $\mathrm{BC}, \mathrm{LC}$, dan CC. Pada tahun 2012 periode aktivitas tebangan tebu $\mathrm{BC}$ berlangsung selama 27 minggu, minggu pertama terhitung 1 April s/d 7 April 2012 dan minggu terakhir terhitung 30 September s/d 6 Oktober 2012 dengan luas tebangan 12.717,52 $\mathrm{Ha}$ dan tahun 2013 berlangsung selama 32 minggu, minggu ke-1 terhitung 1 April s/d 6 April 2013 dan minggu terakhir terhitung 3 Nopember s/d 9 Nopember 2013 dengan luas tebangan 14.093,87 Ha. Sedangkan LC pada tahun 2012 luas tebangan 5.082,59 dan tahun 2013 menjadi 3.695,93 Ha.

Pada awal tebang baik pada BC maupun LC, minggu pertama terhitung 1 April s/d 7 April 2012 luas tebangan masih rendah karena tenaga tebang belum datang semua. Pada minggu ke-16 terhitung tanggal 15 Juli s/d 21 Juli 2012 terjadi penurunan luas tebangan disebabkan karena banyak tenaga yang pulang untuk setor uang kepada keluarganya. Pada minggu ke-21 terhitung 19 Agustus s/d 25 Agustus 2012 terjadi penurunan luas tebangan baik pada $\mathrm{BC}$ maupun LC, hal ini disebabkan karena pengaruh Hari Raya Idul Fitri banyak tenaga tebang yang tidak kerja.

Untuk CC pada tahun 2012 periode aktivitas tebangan tebu hanya berlangsung selama 11 minggu, minggu pertama terhitung 15 Juli s/d 21 Juli 2012 atau minggu ke-16 di tahun 2012 dan minggu ke-11 terhitung 22 September s/d 29 September 2012 atau minggu ke-26 dengan luas tebangan 351,86 Ha dan tahun 2013 periode aktivitas tebangan tebu berlangsung selama 23 minggu, minggu ke-1 terhitung 1 April s/d 6 April 2013 dan minggu ke-32 terhitung 1 September s/d 7 September 2013 dengan luas tebangan 639,60 Ha. Luas tebangan CC pada minggu ke-1 sampai dengan minggu ke- 15 belum ada karena unit Cane harvester dan unit Mega box belum ada. Pada minggu ke-27 luas tebangan $\mathrm{CC}$ tidak ada, hal ini disebabkan karena unit CC mengalami kerusakan sehingga tidak bisa beroperasi.

Pada minggu ke-28 (awal tebang tahun 2013 terhitung tanggal 1 April s/d 6 April 2013) terjadi penurunan luas tebangan baik pada $\mathrm{BC}$ maupun LC, hal ini disebabkan karena pada awal tebangan tenaga tebang belum datang semua. Selanjutnya, pada minggu ke-41 baik pada BC maupun LC kembali mengalami penurunan disebabkan karena sebagian tenaga tebang pulang setor hasil kerjanya kepada keluarga dikampung. Pada minggu ke-46 terlihat terjadi penurunan luas tebangan karena pada periode tersebut menjelang Hari Raya Idul Fitri sehingga tenaga 
sebagian sudah ada yang pulang dan puncaknya pada minggu ke-47 terjadi penurunan luas tebangan yang sangat drastis atau tajam dari periode sebelumnya karena dampak dari Hari Raya Indul Fitri banyak tenaga tebang yang pulang.

Pada minggu ke-52 (tanggal 15 September s/d 21 September 2013) luas tebangan mengalami penurunan baik pada BC maupun LC sebagai imbas kenaikan harga bahan bakar minyak (BBM) dan minggu ke-55 (tanggal 6 Oktober s/d 12 Oktober 2013) kembali mengalami penurunan luas tebangan baik pada BC maupun LC karena menjelang Hari Raya Idul Adha tenaga tebang sudah mulai berkurang (sebagian sudah pulang) dan puncaknya pada minggu ke-56 (tanggal 13 Oktober s/d 19 Oktober 2013) terjadi penurunan yang sangat tajam dari periode minggu sebelumnya karena pada minggu ke-56 tersebut terdapat Hari Raya Idul Adha sehingga tenaga tebang banyak yang pulang.

\section{b. Kemampuan Kirim Maksimal}

Kemampuan kirim maksimal tebu ke pabrik terhadap sistem tebang tebu yang digunakan PT. ILP, yaitu: BC, LC, dan CC selama tahun 2012 dan 2013 terlihat mempunyai kemampuan kirim maksimal yang berbeda. Jumlah kiriman maksimal tebu ke pabrik pada tahun 2012 pada tiga sistem tebang tersebut sebesar 10.740 ton/hari dengan rincian $\mathrm{BC}$ sebesar 6.889 ton/hari; LC sebesar 3.390 ton/hari; dan CC sebesar 461 ton/hari. Selanjutnya, pada tahun 2013 terjadi penurunan sebesar 1.610 ton/hari atau turun sebesar $17,63 \%$ dari tahun 2012 dengan rincian $\mathrm{BC}$ sebesar 6.597 ton/hari; LC sebesar 2.148 ton/hari; dan CC sebesar 385 ton/hari.

Kemampuan kirim maksimal merupakan rata-rata kiriman tebu/minggu dari ketiga sistem tersebut. Pada tahun 2012 periode pengiriman tebu ke pabrik berlangsung selama 27 minggu, minggu pertama terhitung 1 April s/d 7 April 2012 dan minggu terakhir terhitung 30 September s/d 6 Oktober 2012. Sedangkan pada tahun 2013 periode pengiriman tebu ke pabrik berlangsung selama 32 minggu, minggu ke-1 terhitung 1 April s/d 6 April 2013 dan minggu terakhir terhitung 3 Nopember s/d 9 Nopember 2013.

Total kiriman tebu ke pabrik pada tahun 2012 adalah sebesar 1.318.344,54 ton dengan rincian $\mathrm{BC}$ sebesar $927.143,06$ ton; LC sebesar 367.380,66 ton; dan CC sebesar 22.413,10 ton serta gleaning sebesar $1.407,72$ ton. Pada tahun 2013 total kiriman tebu ke pabrik sebesar 1.379.729,36 ton dengan rincian $\mathrm{BC}$ sebesar 1.067.222,92 ton; LC sebesar 270.738,46 ton; dan CC sebesar 41.306,50 ton serta gleaning sebesar 461,48 ton.

Pada awal tebang baik BC maupun LC minggu pertama tahun 2012 (terhitung tanggal 1 April s/d 7 Ápril 2012) dan minggu ke-28 (tanggal 1 April s/d 6 April 2013) jumlah kiriman tebu masih rendah karena tenaga tebang belum datang semua. Pada minggu ke-16 terhitung tanggal 15 Juli s/d 21 Juli 2012 terjadi penurunan jumlah kiriman tebu ke pabrik disebabkan karena banyak tenaga yang pulang untuk setor uang kepada keluarganya. Pada minggu ke-21 terhitung tanggal 19 Agustus s/d 25 Agustus 2012 terjadi penurunan jumlah kiriman tebu ke pabrik baik BC maupun LC, hal ini disebabkan karena pengaruh Hari Raya Idul Fitri banyak tenaga tebang yang tidak kerja. Kiriman tebu ke pabrik CC pada minggu ke-1 sampai dengan minggu ke-15 belum ada karena unit Cane harvester dan unit Mega box belum ada. Pada minggu ke-27 terlihat jumlah kiriman tebu ke pabrik CC tidak ada, hal ini disebabkan karena unit $\mathrm{CC}$ mengalami kerusakan sehingga tidak bisa beroperasi.

Sejalan dengan luas tebangan, pada minggu ke-28 (awal tebang tahun 2013 terhitung tanggal 1 April s/d 6 April 2013) terjadi penurunan jumlah kiriman tebu ke pabrik baik BC maupun LC, hal ini disebabkan karena pada awal tebangan tenaga tebang belum datang semua. Selanjutnya, pada minggu ke-41 (tanggal 30 Juni s/d 6 Juli 2013) baik BC maupun LC kembali mengalami penurunan jumlah kiriman tebu ke pabrik hal disebabkan karena sebagian tenaga tebang pulang setor hasil kerjanya kepada keluarganya dikampung. Selanjutnya, pada minggu ke-46 (tanggal 4 Agustus s/d 10 Agustus 2013) terlihat kembali terjadi penurunan jumlah kiriman tebu ke pabrik hal ini disebabkan karena 
pada periode tersebut menjelang Hari Raya Idul Fitri sehingga tenaga tebang sebagian sudah ada yang pulang dan puncaknya pada minggu ke-47 (tanggal 11 Agustus s/d 17 Agustus 2013) terjadi penurunan jumlah kiriman tebu ke pabrik yang sangat tajam dari periode sebelumnya hal ini merupakan dampak dari Hari Raya Indul Fitri dimana banyak tenaga tebang yang pulang.

Pada minggu ke-52 (tanggal 15 September s/d 21 September 2013) jumlah kiriman tebu ke pabrik mengalami penurunan baik BC maupun LC hal ini disebabkan sebagai imbas kenaikan harga bahan bakar minyak (BBM) dan minggu ke-55 (tanggal 6 Oktober s/d 12 Oktober 2013) kembali mengalami penurunan jumlah kiriman tebu ke pabrik baik BC maupun LC karena menjelang Hari Raya Idul Adha sehingga tenaga tebang sudah mulai berkurang (sebagian sudah pulang) dan puncaknya pada minggu ke-56 (tanggal 13 Oktober s/d 19 Oktober 2013) terjadi penurunan yang sangat tajam dari periode minggu sebelumnya karena pada minggu ke-56 tersebut terdapat Hari Raya Idul Adha sehingga tenaga tebang banyak yang pulang.

\section{c. Ketersediaan Tenaga}

Ketersediaan tenaga kerja tebang BC pada tahun 2012 rata-rata 2.296 orang/hari dan tahun 2013 meningkat $0,78 \%$ atau menjadi 2.314 orang/hari sedangkan LC tahun 2012 sebanyak 2.074 orang/hari dan tahun 2013 mengalami penurunan yang cukup besar yaitu $140,05 \%$ atau turun menjadi 1.210 orang/hari. Penurunan jumlah tenaga kerja LC disebabkan karena adanya kebijakan manajemen perusahaan untuk mengurangi tenaga kerja LC di satu sisi dan dilain sisi meningkatkan atau mengoptimalkan BC. Disamping itu, dikarenakan rata-rata musim panen tebu di Indonesia adalah bersamaan, jadi akan terjadi persaingan dalam mendapatkan tenaga kerja antar Pabrik Gula yang rata-rata menggunakan BC. Sedangkan ketersediaan jumlah unit $\mathrm{CC}$ adalah sangat terbatas karena biaya pengadaan dan operasional $\mathrm{CC}$ cukup mahal sehingga ketersediaan jumlah unit $\mathrm{CC}$ disesuaikan dengan kemampuan perusahaan. Jumlah unit CC pada tahun 2012 berjumlah 1 unit dan tahun 2013 bertambah menjadi 2 unit.

\section{d. Ketersediaan Armada Angkut}

Armada angkut $\mathrm{BC}$ adalah berupa unit truck. Ketersediaan armada angkut BC pada tahun 2012 berjumlah 207 unit dan pada tahun 2013 meningkat $10 \%$ (23 unit) sedangkan jumlah armada angkut LC pada tahun 2012 berjumlah 17 unit dan tahun 2013 meningkat 5,56\% (1 unit). Jenis armada angkut LC adalah tronton yang juga jumlahnya sangat terbatas. Armada angkut CC juga berupa tronton mega box (bak rapat). Jumlah armada angkut yang dimiliki perusahaan sangat terbatas. Pada tahun 2012 rata-rata jumlah mega box yang beroperasi adalah 5 unit dan pada tahun 2013 bertambah menjadi 6 unit.

\section{e. Persentase Kiriman saat Hujan}

Kendala angkut tebu yang paling besar adalah hujan. Pada saat hujan proses angkut tebu akan mengalami hambatan, sehingga dapat mengakibatkan penurunan. Persentase kiriman terendah tebu saat hujan pada BC pada tahun 2012 adalah 696 ton atau $10 \%$ terhadap total kemampuan kirim maksimal dan tahun 2013 yaitu 628 ton atau 9,5\% terhadap total kemampuan kirim maksimal BC. Sedangkan persentase kiriman terendah tebu saat hujan pada LC pada tahun 2012 adalah $10,90 \%$ (371 ton) terhadap total kemampuan kirim maksimal dan tahun 2013 meningkat menjadi 32,10\% (688 ton) terhadap total kemampuan kirim maksimal LC. Persentase kiriman terendah tebu saat hujan pada CC pada tahun 2012 adalah $15,80 \%$ atau 73 ton terhadap total kemampuan kirim maksimal dan pada tahun 2013 menjadi $21,60 \%$ atau 83 ton terhadap total kemampuan kirim maksimal CC.

\section{f. Biaya Variabel}

Biaya dalam proses pengiriman tebu dapat bervariasi berdasarkan jumlah kiriman. Biaya tersebut dapat dikonversi ke dalam satuan per ton tebu yang terkirim ke pabrik baik $\mathrm{BC}$ maupun LC. Biaya variabel yang dimaksud adalah keseluruhan biaya tebangan ditambahkan biaya variabel angkutan. Rata-rata biaya variabel BC tahun 2012 adalah Rp.55.600 per ton dan meningkat menjadi Rp.59.681 per ton tahun 2013 atau meningkat $6,84 \%$ sedangkan LC, rata-rata biaya variabel tahun 2012 adalah Rp.82.821,29 per ton dan pada tahun 2013 meningkat 22,52\% (Rp.106.897,27 per ton). 
Biaya variabel per ton tebu tersebut merupakan harga dasar tebang tebu. Komponen dalam penentuan harga dasar tebang tebu adalah tebangan, operasional kontraktor, transport, insentif sopir, dan insentif tebu bersih. Harga dasar BC tahun 2012 sebesar Rp.52.100 per ton dan pada tahun 2013 ada kenaikan yakni 7,83\% atau menjadi Rp.56.526 per ton demikian pula incentive transport terjadi kenaikan $20,05 \%$ dari Rp.36.759 per ton menjadi Rp.45.968 per ton dan incentive tebangan dari Rp.9.250 per ton menjadi Rp.9.282 per ton tebu atau terdapat kenaikan $0,34 \%$ sedangkan tebu tertinggal tidak terdapat kenaikan (Rp.6.000 per ton). Sedangkan LC harga dasar tebang terdapat kenaikan 7,64\% yakni dari Rp.2.977.400 per hektar tahun 2012 menjadi Rp.3.223.628 per hektar tahun 2013 dan inventive naik 4,12\% yakni dari Rp. 180.000 per hektar tahun 2012 menjadi Rp.187.740 per hektar tahun 2013 sedangkan penalty baik dalam bentuk tanpa ikat maupun tebu kotor tidak terdapat kenaikan yakni tetap Rp.231.000 per hektar.

\section{g. Tambahan Biaya Variabel}

Pada saat hujan, untuk melakukan proses muat BC dilakukan diluar petak. Penebang akan mendapatkan tambahan upah berupa insentif langsir. Penambahan biaya untuk LC muncul karena adanya proses bundleing yang dilakukan oleh GL (Grab Loader) dengan menggunakan tenaga manusia. Berdasarkan data lapangan, man days per hektar untuk mengeluarkan tebu adalah 50 orang. Rata-rata tambahan biaya variabel per ton tebu BC pada tahun 2012 adalah Rp.5.750 per ton tebu dan meningkat menjadi Rp.5.782 per ton tebu atau naik $0,55 \%$ pada tahun 2013 sedangkan LC, rata-rata tambahan biaya variabel tahun 2012 adalah Rp.27.291,67 per ton tebu dan tahun 2013 meningkat 13,61\% atau naik menjadi Rp.32.083,33 per ton tebu. Peningkatan tambahan biaya variabel LC disebabkan karena adanya peningkatan upah tenaga kerja per hari dari Rp.39.300 per ton tebu pada tahun 2012 menjadi Rp.46.200 per ton tebu pada tahun 2013 atau ada kenaikan upah tenaga kerja sebesar $14,94 \%$.

\section{Kuota Harian Pabrik}

Kiriman tebu dapat menjadi parameter untuk produksi gula. Kiriman tebu per hari didasarkan pada kuota pabrik PT. ILP yaitu 8.500 ton/hari. Rata-rata kiriman tebu ke pabrik BC tahun 2012 adalah 6.889 ton dan tahun 2013 lebih rendah 292 ton (6.597 ton); LC tahun 2012 yakni 3.390 ton dan tahun 2013 turun menjadi 2.147 ton sedangkan CC tahun 2012 sebesar 468 ton dan tahun 2013 menjadi 385 ton. Dengan demikian, ketiga sistem tebang tersebut tahun 2013 cenderung mengalami penurunan dibanding tahun 2012.

Hasil penelitian menunjukkan bahwa rerata kiriman tebu ke pabrik antara BC, LC dan CC secara statistik menunjukkan perbedaan yang nyata pada tingkat kepercayaan 99\%. Karena terdapat perbedaan rerata kiriman tebu antara $\mathrm{BC}$, LC dan CC maka dilakukan uji lanjut dengan menggunakan analisis perbedaan rerata (uji-t) dua rerata diantara ketiga sistem tebang tersebut, yaitu membandingkan rata-rata kiriman tebu $\mathrm{BC}$, LC dan CC.

Hasil penelitian menunjukkan bahwa antara BC dan LC sebesar 3.974 ton per hari dan secara statistik menunjukkan perbedaan yang signifikan pada tingkat kepercayaan 95\%. Selanjutnya, antara $\mathrm{BC}$ dengan $\mathrm{CC}$ terdapat perbedaan rerata kiriman tebu ke pabrik sebesar 6.320 ton per hari dan signifikan pada tingkat kepercayaan $99 \%$. Sedangkan antara LC dengan CC terdapat perbedaan rerata kiriman tebu ke pabrik sebesar 2.346 ton per hari dan signifikan pada tingkat kepercayaan 90\%. Dengan demikian, ketiga sistem tebang tersebut secara statistik menunjukkan perbedaan yang signifikan dalam kiriman tebu ke pabrik dimana $\mathrm{BC}$ paling tinggi disusul LC dan paling kecil adalah CC.

\section{Struktur Neraca Komposisi Rerata Kiriman Tebu}

Hasil penelitian menunjukkan bahwa pada kondisi aktual merupakan rerata kiriman tebu BC, LC dan CC ke pabrik PT. ILP tahun 2012 yaitu sebesar 10.747 ton per hari yakni BC mendapatkan alokasi atau mampu melakukan pengiriman tebu ke pabrik sebesar 6.889 ton per hari atau $64,10 \%$ terhadap total kiriman tebu ke pabrik PT. ILP sedangkan pada kondisi optimal 
(hasil simulasi) terlihat adanya penambahan alokasi kiriman tebu menjadi 7.096 ton per hari atau naik menjadi $64,71 \%$.

Selanjutnya, LC pada kondisi aktual mendapatkan alokasi atau mampu melakukan pengiriman tebu sebesar 3.390 ton per hari atau $31,54 \%$ terhadap total kiriman tebu ke pabrik PT. ILP. Setelah dilakukan simulasi dengan memperhatikan faktor kendala yang ada, rerata kiriman tebu LC menjadi 3.407 ton per hari atau naik menjadi 31,07\%. Pada CC pada kondisi aktual mendapatkan alokasi atau mampu melakukan pengiriman tebu ke pabrik PT. ILP sekitar 4,35\% (468 ton per hari) terhadap total kiriman tebu ke pabrik dan pada kondisi optimal mendapatkan alokasi kiriman tebu sebanyak 463 ton per hari atau 4,22\%. Pada hasil simulasi terlihat bahwa BC dan LC terlihat adanya peningkatan alokasi pengiriman tebu sedangkan CC terlihat adanya penurunan sekitar $0,13 \%$. Penataan struktur neraca komposisi rerata kiriman tebu BC, LC dan CC PT. ILP yang ideal (hasil optimasi) tahun 2012 pada Tabel 1.
$72,26 \%$ terhadap total kiriman tebu ke pabrik PT. ILP sedangkan pada kondisi optimal terlihat adanya penambahan alokasi kiriman tebu menjadi 6.827 ton per hari atau naik menjadi $72,79 \%$. Penataan struktur neraca komposisi rerata kiriman tebu pada BC, LC dan CC PT. ILP yang ideal (hasil optimasi) tahun 2013 pada Tabel 2.

LC mendapatkan alokasi atau mampu melakukan pengiriman tebu sebesar 2.147 ton/hari atau $23,52 \%$ terhadap total kiriman tebu ke pabrik dan setelah dilakukan simulasi dengan memperhatikan faktor kendala yang ada, rerata kiriman tebu LC naik menjadi 2.166 ton per hari. CC mendapatkan alokasi atau mampu melakukan pengiriman tebu ke pabrik sekitar 4,22\% (385 ton per hari) terhadap total kiriman tebu ke pabrik dan pada kondisi optimal mendapatkan alokasi kiriman tebu sebanyak 386 ton per hari atau mendapatkan proporsi sekitar $4,12 \%$ terhadap total kiriman tebu ke pabrik.

Dari hasil analisis tersebut dapat memberikan gambaran bahwa sistem pengiriman

Tabel 1. Penataan Struktur Neraca Komposisi Rerata Kiriman Tebu pada BC, LC dan CC PT. ILP yang Ideal Tahun 2012

\begin{tabular}{|c|l|r|r|r|r|}
\hline \multirow{2}{*}{ No. } & \multicolumn{2}{|c|}{ Sistem Tebang } & \multicolumn{3}{|c|}{ Rerata Kiriman Tebu (ton/hari) } \\
\cline { 3 - 6 } & & \multicolumn{3}{|c|}{ Aktual } & \multicolumn{2}{|c|}{ Optimal } \\
\hline 1. & Bundle Cane & 6.889 & 64,10 & 7.096 & 64,71 \\
2. & Loose Cane & 3.390 & 31,54 & 3.407 & 31,07 \\
3. & Chopped Cane & 468 & 4,35 & 463 & 4,22 \\
\hline \multicolumn{2}{|c|}{ Total Kiriman Tebu } & $\mathbf{1 0 . 7 4 7}$ & $\mathbf{1 0 0 , 0 0}$ & $\mathbf{1 0 . 9 6 6}$ & $\mathbf{1 0 0 , 0 0}$ \\
\hline
\end{tabular}

Sumber: data sekunder, diolah

Tabel 2. Penataan Struktur Neraca Komposisi Rerata Kiriman Tebu pada BC, LC dan CC PT. ILP yang Ideal Tahun 2013

\begin{tabular}{|c|l|r|r|r|r|}
\hline \multirow{2}{*}{ No. } & \multirow{2}{*}{ Sistem Tebang } & \multicolumn{3}{|c|}{ Rerata Kiriman Tebu (ton/hari) } \\
\cline { 3 - 6 } & & \multicolumn{3}{|c|}{ Aktual } & \multicolumn{2}{c|}{ Optimal } \\
\hline 1. & Bundle Cane & 6.597 & 72,26 & 6.827 & 72,79 \\
2. & Loose Cane & 2.147 & 23,52 & 2.166 & 23,09 \\
3. & Chopped Cane & 385 & 4,22 & 386 & 4,12 \\
\hline \multicolumn{2}{|c|}{ Total Kiriman Tebu } & $\mathbf{1 0 . 7 4 7}$ & $\mathbf{1 0 0 , 0 0}$ & $\mathbf{9 . 3 7 9}$ & $\mathbf{1 0 0 , 0 0}$ \\
\hline
\end{tabular}

Sumber: data sekunder, diolah

Pada Tabel 2 menunjukkan kiriman tebu tahun 2013 pada kondisi aktual terlihat total kiriman tebu ke pabrik PT. ILP lebih rendah dari tahun sebelumnya (tahun 2012) yakni 9.938 ton per hari yakni pada sistem tebang BC mendapatkan alokasi atau mampu melakukan pengiriman tebu sebesar 6.597 ton per hari atau tebu ke pabrik PT. ILP dengan menggunakan tiga sistem pengiriman (BC, LC dan CC) selama ini belum optimal. Hal ini disebabkan karena sistem pengiriman tebu ke pabrik PT. ILP selama ini hanya melihat trend perkembangan jumlah kiriman tebu ke pabrik dari waktu ke waktu sehingga kurang mempertimbangkan dengan 
cermat kendala-kendala yang ada pada ketiga sistem tebang tersebut. Ketidakefisienan tersebut dapat terlihat pada Tabel 1 dan Tabel 2 pada kolom aktual karena setelah dilakukan simulasi terlihat adanya perubahan komposisi alokasi kiriman tebu ke pabrik PT. ILP pada ketiga sistem tebang pada kolom optimal. Perubahan tersebut tentunya sangat mempertimbangkan kendala-kendala yang ada yaitu: kemampuan kirim tebu maksimal; jumlah tenaga tebang $\mathrm{BC}$, LC dan $\mathrm{CC}$; jumlah unit $\mathrm{CC}$; jumlah armada angkut $\mathrm{BC}$, $\mathrm{LC}$ dan $\mathrm{CC}$; rata-rata kiriman terendah tebu pada saat hujan BC, LC dan CC; biaya variabel per ton tebu $\mathrm{BC}, \mathrm{LC}$ dan $\mathrm{CC}$; tambahan biaya variabel per ton $\mathrm{BC}, \mathrm{LC}$ dan $\mathrm{CC}$ saat hujan; dan luas tebangan BC, LC dan CC. Dengan demikian, perubahan komposisi kiriman tebu tersebut tentunya juga akan berdampak terhadap perubahan komposisi biaya pengiriman yang terjadi pada ketiga sistem tebang tersebut.

Analisis sensitivitas pada perencanaan kiriman tebu pada BC, LC dan CC ke pabrik PT. ILP dilakukan terhadap perubahan jumlah tenaga kerja tebang dan perubahan biaya variabel tebang tebu per ton. Simulasi perubahan terhadap kedua variabel tersebut dilakukan dengan menaikkan jumlah tenaga kerja tebang dan biaya variabel tebu per ton dari $5 \%, 10 \%, 15 \%$ dan $20 \%$. Berdasarkan hasil simulasi menunjukkan adanya perubahan komposisi kiriman tebu dari kondisi normal baik tahun 2012 maupun 2013. Hasil perhitungan berdasarkan simulasi menunjukkan bahwa dengan menaikkan jumlah tenaga kerja tebang sebesar $10 \%$ dari kondisi saat ini dapat memberikan tingkat optimalisasi yang paling baik karena paling mendekati komposisi kiriman yang diharapkan oleh perusahaan yakni BC sebesar 70\%; LC sebesar 25\%; dan CC sebesar $5 \%$ terhadap total kiriman tebu ke pabrik.

\section{KESIMPULAN}

Berdasarkan hasil analisis data dan pembahasan yang dilakukan berkenaan dengan tujuan penelitian, dapat disimpulkan sebagai berikut:

a. Terdapat perbedaan rerata kiriman tebu ke pabrik PT. ILP dari sistem BC, LC dan CC dimana sistem tebang $\mathrm{BC}$ paling tinggi disusul sistem tebang LC dan paling kecil adalah sistem tebang CC.

b. Komposisi rerata kiriman dari sistem tebang $\mathrm{BC}, \mathrm{LC}$ dan $\mathrm{CC}$ saat ini belum optimal dalam memenuhi kuota pabrik. Hal ini terlihat dari komposisi pengalokasian kiriman tebu ke pabrik PT. ILP pada masing-masing sistem tebang (BC, LC dan CC) mengalami perubahan komposisi pengalokasian dari sebelumnya sehingga adanya perubahan komposisi tersebut masih dapat diperoleh produksi gula yang lebih tinggi dari sebelumnya (masih dapat ditingkatkan).

\section{DAFTAR PUSTAKA}

Asri, M dan Wahyu Hidayat, 1986. Linear Programming. Edisi Revisi. Badan Penerbit Fakultas Ekonomi UGM. Yogyakarta.

Beneke. R. R. And R. Winterboer. 1973. Linear Programming Aplications to Agriculture. The lowa State University Press, Ames.

Birowo,A.T.,Dr Dibyo Prabowo, Ir. Poerwadi Djojonegoro. 1992. Perkebunan Gula. LPP. Yogyakarta

Darwanto, Dwijono.1982. Ekonomi Produksi Pertanian Hand Out Proyek Peningkatan Perguruan Tinggi. UGM. Yogyakarta

Debertin, David L. 1986. Agriculture Production Economics. Mac Millan Publishing Company. New York.

Dimyati, at al., 2010. Operations Research: Model-Model Pengambilan Keputusan. Cetakan Kesebelas. Sinar Baru Algensindo. Bandung.

Hartono, Slamet, 2000. Riset Operasi - Bahan Kuliah Program Studi Magister Manajemen Agribisnis, Pasca Sarjana Universitas Gadjah Mada - Yogyakarta.

Heady, E. O. And W. Candler. 1960. Linear Programming Methods. The lowa State.

Kakiay, Thomas J., 2008. Pemrograman Linier: Metode dan Problema. Penerbit ANDI Yogyakarta.

Kuspratomo, A. D. , dan Muhammad Fakhry. Pengaruh Varietas Tebu, Potongan dan Penundaan Giling Terhadap Kualitas Nira Tebu. Jurnal AGROINTEK Vol 6, No. 2. 
Moh Nasir, PhD., 1983. Metode Penelitian. Ghalia Indonesia. Penerbit Balai AksaraPenerbit Yudishtira dan Pustaka Saadiyah.

Nasendi B.D. dan Affendi Anwar, 1985. Program Linear dan Variasinya. Penerbit PT. Gramedia, Jakarta.

Santoso., B. E. 2002. Rendemen: definisi, prosedur dan kaitannya dengan kinerja pabrik. Pasuruan: P3GI

Siswanto, 1990. Sistem Komputer Manajeman. Management Science. PT. Elex Media Komputindo, Jakarta.

Soekartawi. 1994. Teori Ekonomi Produksi dengan Pokok Bahasan Analisis Fungsi Cob-Douglas. Rajawali. Jakarta.

Subagyo dkk, 2013. Dasar-dasar Operastion Research. Edisi Kedua. BPFE UGM. Yogyakarta.

Supranto J. 1979. Liniear Programming. Lembaga Penerbit Fakultas Ekonomi Universitas Indonesia. Jakarta.

Taha, H.A., 1996. Riset Operasi. Suatu Pengantar. Edisi ke-5 Jilid I. Bina Rupa Aksara. Indonesia. 